\title{
A118 生分解性樹脂複合材料による組織再生用足場の機能評価 \\ Functional Estimasion of Scaffold Using Biodegradable Polymer Composite
}

\author{
○学 沖添晃政 (神戸大) 正 日和 千秋 (神戸大) \\ 正 中井 善一（神戸大） 正 安達 泰治（京都大）
}

Terumasa OKIZOE, Chiaki HIWA, Yoshikazu NAKAI, Kobe University, Nada, Kobe 657-8501

Taiji ADACHI, Kyoto University, Yoshida-Honmachi, Sakyo-ku, Kyoto 606-8501

\section{1. 諸 言}

生分解性高分子材料である PLA(Poly lactic acid)や PCL(Poly caprolactone)樹脂は, 生体適合性に優れており, 組織再生用足 場(スカフォールド)のための材料として期待されている.

スカフォールドに必要な特性として, 細胞の成長のため高 い空孔率を有しており，生体適合性に優れていること，生分 解とその吸収速度が生体に合うように制御できること, 細胞 の着床，増殖に適した化学的性質を有しており，そして機械 的特性に優れていることなどが上げられている．またスカフ オールドへの細胞などの播種性も重要である.

本研究では高強度で高勒性の PLA 繊維と, 柔軟性に優れた PCL 樹脂によって複合材料とすることで，歯槽骨への適用を ターゲットとし, 細胞の播種性と臨床時の取り扱いが良く, 汎用性に優れたスカフォールドの開発を行った。 また，開発 したスカフォールドの in vitro での機械的特性や生分解特性 および骨形成過程を検討した。

\section{2. 試験方法}

\section{1 試験片の作成方法}

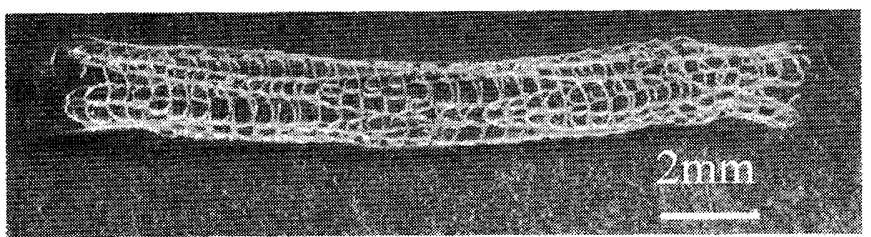

(a) Fabric structure.

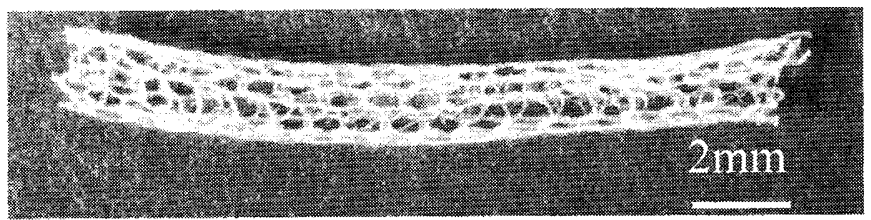

(b) Composite.

Fig.1 Specimen geometry.

PLA 樹脂と PCL 樹脂はともに FDA(米国食品医薬品局)認 可の医療用（API 社製）のものを使用した。 PLA 樹脂はクリ ーンルームに置かれた射出成形機で $1.0 \mathrm{~mm}$ 径の繊維に作成 した後，二次延伸処理を行って直径 $0.07 \mathrm{~mm} の$ PLA 繊維とし
た.この繊維の引張強度は約 $200 \mathrm{MPa}$ であった。これを用い て図 1 (a)に示すようなカゴ状の織物構造体を作成した。

その後, 繊維による織物構造体を, アセトンで PCL 樹脂を 溶かしたソルベントに浸し乾燥させ繊維交差部を接着して, 図 2(b)のような直径約 $2 \mathrm{~mm}$ の複合材料を作成した.ここから 長さ $20 \mathrm{~mm}$ に切断してスカフォールドの試験片として使用し た. また以上の作業はクリーンベンチ内で行い, 作成後, $\gamma$ 線による滅菌を施した。

\section{2 細胞培盖}

細胞はマウスの骨芽細胞様細胞(MC3T3-E1，理研 BRC)を用 いた．使用した培地は $\alpha$-MEM（ $\alpha$-Minimal essential medium） に $10 \%$ のウシ胎児血清, $2 \mathrm{mM}$ の L-グルタミン, $100 \mu \mathrm{g} / \mathrm{ml}$ の抗 生物質を加え，更に $50 \mu \mathrm{g} / \mathrm{ml}$ のアスコルビン酸，10 $\mathrm{mM}$ の $\beta$ グリセロリン酸を加えたものを使用した ${ }^{1)}{ }^{2}$. 培養期間は, 1, 2, 4,6 および 8 週とし，ALP (Alkaline phosphatase). 活性, DNA 量およびカルシウム量の測定を行い，更に ALP，カルシウム を染色し，観察した。ここでは，スカフォールドと比較するた めに，細胞を同時にディッシュでも培養した。

ALP 活性およびDNA 量の測定については $0.2 \%$ のポリオキ シエチレン(10)オクチルフェニルェーテル, $10 \mathrm{mM} の$ Tris- $\mathrm{HCl}$, $1 \mathrm{mM}$ の $\mathrm{MgCl}_{2}$ を混合した $\mathrm{pH} 7.5$ の溶液で抽出した. ALP 活性 の測定は p-ニトロフェニルリン酸を基質とした ALP 活性測 定キット(Wako LabAssay ${ }^{\mathrm{TM}} \mathrm{ALP}$ ，和光純薬製)を用い，マイク プレートリーダーで $405 \mathrm{~nm}$ の吸光度を測定した ${ }^{3)}$. DNA 量に ついては $0.1 \mu \mathrm{g} / \mathrm{ml}$ の Hoechst33258, 10mM の Tris-HCl, 1mM の Na2EDTA，0.1mM の NaCl を混合した溶液を用いて蛍光光 度計で測定した。

カルシウム量については $10 \%$ の゙酸 $1 \mathrm{~mL}$ で 30 分間, 室温 で抽出し, 测定キット(カルシウム C-テストワコー, 和光純 薬製)を用いてマイクプレートリーダーで $570 \mathrm{~nm}$ の吸光度を 測定した。

ALP 染色については ALP 染色キット(No.1568-2, 武藤化学) を用いて染色し，カルシウムは Von Kossa 染色により観察し た. 


\section{3 試験方法}

スカフォールドの生分解による機械的性質の変化を観察す るために小型引張り試験機(容量 50N, 東栄産業, MT-101)で引 張り試験を行った。 また, 物理的性質の変化を観察するため にDSC (示差走查熱量計, DSC-60，株島津製作所製)による熱 分析を行った.

\section{3. 試験結果と考察}

ALP 活性の結果を Fig.2, カルシウム量の変化を Fig.3, ALP 染色を Fig.4 に示す. ALP 活性は単位 DNA 量あたりに換 算し, $\mathrm{pH} 9.8,37^{\circ} \mathrm{C}$ で, 1 分間に $1 \mathrm{nmol}$ の p-フェノールを生成す る酵素活性を 1 unit としている. ALP 活性では有意義水準 $5 \%$ で $\mathrm{t}$ 検定すると, 2 6週のデータについてディッシュとスカフ オールドの活性に有意義が認められた．また，カルシウム量 に関して有意義水準 5\%で $\mathrm{t}$ 検定すると 6 および 8 週において ディッシュとスカフォールドのカルシウム量に有意義が認め られた。

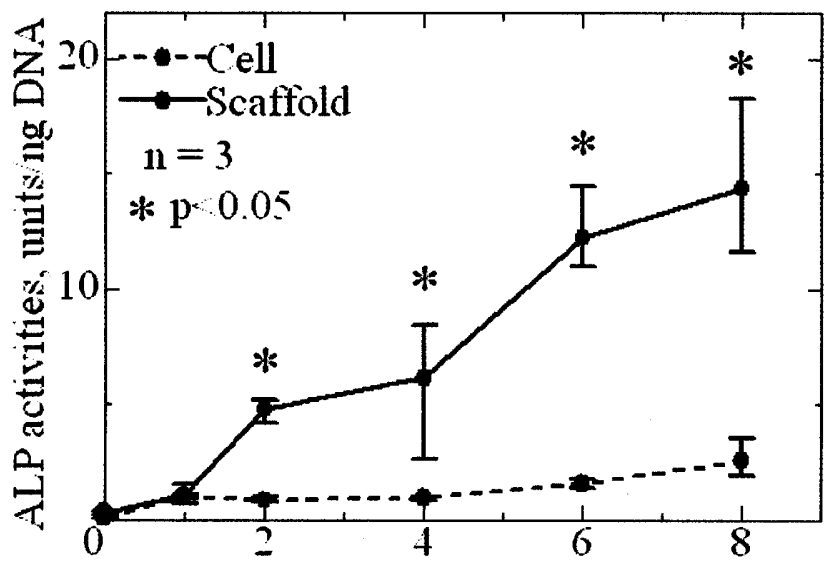

Time, weeks

Fig.2 Change of ALP activities.

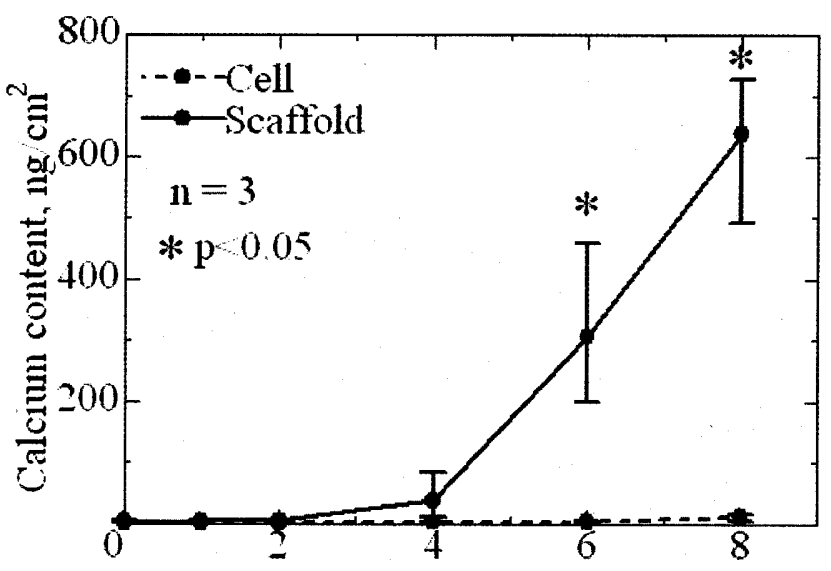

Time, weeks
Fig.2 を見るとディッシュで培養したものに比ベスカフォ 一ルドで培養したほうが ALP 活性の上昇が大きい。これは, ディッシュ上では 2 次元の培養になるが, スカフォールドで は 3 次元での培養となるので, 形状の違いによる影響が考え られる。

また, Fig.3 を見るとスカフォールドでは, 4 週でカルシウム が生成してきて, その後, 大きく増加しているのが分かる.デ イッシュで培養したものでもカルシウムは生成しているが， スカフォールドに比べると量はとても少ない。この結果より， ALP 活性が大きくなるにつれて生成するカルシウム量も大き くなると考えられる．また，形状の違いによる影響も考えら れる。

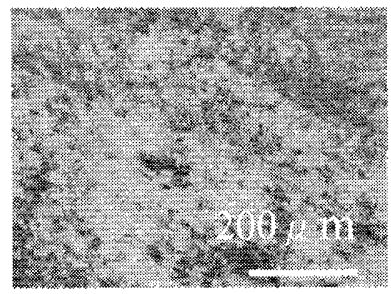

(a) Dish

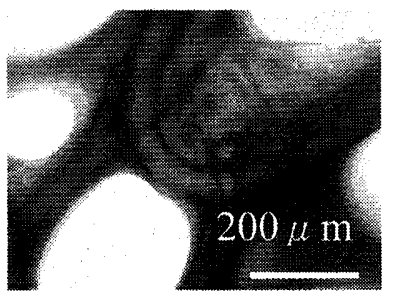

(b) Scaffold
Fig.4 ALP stain (1week).

Fig.4を見ると，一週間でALPが染色されているのが分かる. その後もALP は染色されており,また時間の経過と共に色が 濃くなっており ALP 活性が上昇していることが分かった。

スカフォールドの生分解による機械的性質の変化，および 物理的性質の変化は当日に発表する.

なお本研究の一部は, (独) 科学技術振興機構研究成果活用 プラザ京都における育成研究課題として行ったものである.

また本研究は平成 17 年度科学研究費(基盤研究(c)課題番号 17560070)の補助を受けた。ここに謝意を示す。

\section{参考文献}

1. Lennie D. Shea, Ph. D., Dian Wang, Renny T. Franceschi, David J. Mooney, Ph.D., Tissue Engineering, 6 , pp.605-617 (2000).

2. C. Maniatopoulos, J. Sodek, A.H. Melcher, Cell Tissue Res, 254, pp.317-330 (1988).

3. Masaya Yamamoto, Yoshitake Takahashi, Yasuhiko Tabata, Biomaterials, pp.4375-438924 (2003).

Fig.3 Change of Calcium content. 